INDEPENDENT JOURNAL OF MANAGEMENT \& PRODUCTION (IJM\&P)

http://www.ijmp.jor.br

v. 8, n. 3, July - September 2017

ISSN: 2236-269X

DOI: 10.14807/ijmp.v8i3.622

\title{
IDENTIFYING AND PRIORITIZING FACTORS AFFECTING THE CUSTOMERS' WILLINGNESS TO BUY GOODS PRODUCT INSIDE THAN ON THE OUTSIDE (CASE STUDY: IRAN TRANSFO CORPORATION)
}

Haleh Keshavarz Afshar Islamic Azad University of Medical Sciences, Iran, Islamic Republic of E-mail: Haleh.k88@yahoo.com

Gholamreza Soleimani Islamic Azad University of Medical Sciences, Iran, Islamic Republic of E-mail: GH_Soleimani2006@yahoo.com

Submission: 26/01/2017 Accept: 01/03/2017

\section{ABSTRACT}

The present study aims to identify and prioritizing factors affecting customers' willingness to purchase domestic goods than the foreign ones in Iran Transfo Corporation in 2016. The statistical population includes all customers and a sample of 200 subjects (175 male, 25 female). Respondents' evaluation of the variables indicates that Iranian goods enjoy market-product fit (0.85), good performance (0.41), relative reputation and validity $(0.44)$, high reliability $(0.36)$, good communication methods (0.34) and relative value (0.26). Finally, $88 \%$ prefer to purchase Iranian goods. The effect of 7 independent variables and purchase preferences are significant at (e $<0.05)$. The results of inferential statistics show that there is a significant relationship between willingness to purchase domestic and foreign goods. There is a significant difference between marketing methods and satisfaction among buyers of domestic and foreign goods as well. But, there is no significant difference between the customers' evaluation of product features and performance of domestic producers compared to the foreign ones. Finally, given that the majority of respondents considered marketing methods inappropriate, therefore, it's recommended that companies adopt new policies to better sell their products.

Keywords: Consumer Behavior, Marketing Strategy, Purchase

Preferences, Domestic and Foreign Goods, Iran Transfo Corporation 
INDEPENDENT JOURNAL OF MANAGEMENT \& PRODUCTION (IJM\&P)

http://www.ijmp.jor.br

v. 8, n. 3, July - September 2017

ISSN: 2236-269X

DOI: 10.14807/ijmp.v8i3.622

\section{INTRODUCTION}

World trade expansionist of utmost importance for the growth and development of the whole world economy. This is important, in particular for countries that face a lack of resources. However, commercial transactions (especially imports) could sometimes leave negative outcomes within the countries.

When the domestic industries (due to different reasons)are unable to compete with similar foreign products or when new methods of marketing for many products that are competitive with foreign brands are ignored, imports impose a double pressure on domestic production and customers are increasingly exposed to a wide range of imported products (KNIGHT, 1999).

Several factors in our country have made many industries unable to easily compete with similar foreign products. Currently, foreign products in many cases have attracted customers, and consumers' priority is to choose the foreign goods rather than the domestic one. Here an important question is posed: What is the reason behind consumers' willingness to buy foreign goods?

In response to this question, some say it's the wrong culture that is prevailing the community and some refer to the better quality of foreign products; both of these theories have considered some reasons as the main cause. But the reality is that consumers' willingness to consume foreign products in our country stems from a series of factors, one of which is wrong culture of the society (consumer needs and beliefs).

The other is related to the malfunction of manufacturers, product specifications, and poor performance of governmental organizations and the weakness of rules and regulations and so on.

Attitudes, manner and performance of manufacturer in producing and supplying the products are one of the main reasons for the consumers' willingness to buying or leaving the products. Manufacturers who focus their activities purely on gaining profit in a short time period, cannot hope to produce and sell their products (in the long-term), in contrast, manufacturers who consider customer preferences and produce products tailored to their needs and tastes (in terms of price, diversity, performance, standard, etc.) could be a factor for further production and sale in the 
INDEPENDENT JOURNAL OF MANAGEMENT \& PRODUCTION (IJM\&P)

http://www.ijmp.jor.br

v. 8, n. 3, July - September 2017

ISSN: 2236-269X

DOI: 10.14807/ijmp.v8i3.622

long term. International standards and products featuring them are considered as an advantage.

Some foreign products supplied in our country have the latest international standards which also account for the consumers' willingness to buy them. In contrast, some other similar domestic goods have even failed to achieve the standards of our own country, such as the automobile industry, etc (ELECTRONIC JOURNAL BHKAM, 2016).

These factors can increase customer satisfaction and customer preferences. Customer satisfaction is undoubtedly one of the strategic issues in recent decades occupying the marketing managers' minds to provide a proper strategy to gain the trust of customers to the domestic goods. Iran Transfo Corporation is not an exception, being the largest manufacturer and exporter of transformers under license from Germany Siemens in the Middle East.

Many factors affect people's decisions to buy domestic products, attracting the attention of scholars and researchers since many years ago. In 1950s, realizing the customers and their needs was prioritized to raw materials and selling skills. Freud's ideas were used by the marketers and researchers. Also in the 1960s, consumer behavior became the main concern of studies, meaning that commercial firms aimed at satisfying the demands and needs of consumers through understanding the transaction parties.

Although transaction is an important part of consumer behavior, but broader perspectives today stress the whole consumption process involving factors affecting consumer behavior before, during and after the purchase. Accordingly, internal and external practical investigations have been carried out in this field and purchase decisions; for example, the research results of Sadeghi et al. (2014) showed that consumer shopping preferences include: quality, standard, diversity and greater durability of foreign products, the sellers also state that increased prices of raw material and consequently expensive domestic goods against cheap foreign goods, and false culture that implies foreign goods are better are among such factors (SADEGHI, et al., 2014).

Heydarzadeh and Hasaniparsa (2013) also found that hedonistic values have a positive effect on increasing novelty seeking brand consciousness, responsiveness 
INDEPENDENT JOURNAL OF MANAGEMENT \& PRODUCTION (IJM\&P)

http://www.ijmp.jor.br

v. 8, n. 3, July - September 2017

ISSN: 2236-269X

DOI: 10.14807/ijmp.v8i3.622

to promotion stimuli, and preference for foreign brands (HEYDARZADEH; HASANIPARSA, 2013). Mahmoudi Meymand, et al. (2013) stated that personality types have a significant difference in the attitudes of consumer towards involvement variables, knowledge and willingness to purchase (MAHMOUDI MEYMAND et al., 2013).

The results of Heidarzadeh et al. (2010) showed that customers studied have a different assessment of the characteristics of goods, related marketing methods and purchase preferences of the goods in two countries. By prioritizing factors affecting the purchase preferences, companies operating in the market can use them to optimize their marketing strategy (HEIDARZADEH, et al., 2010).

Haghighi and Hosseinzadeh (2008) in a study argued that consumers with high nationalism consumption(compared to consumers with low consumption nationalism) have a better assessment of domestic goods, but closer examination showed that these consumers evaluate the domestic goods less favorable that the foreign goods (HAGHIGHI; HOSSEINZADEH, 2008).

Study done by Isaac Cheah et.al. (2016) argued that customer's hostility is shown by economic hostility and war. In such circumstances, the immense hostility and ethnicity of customers does not play a significant role in affecting other areas in the hostility model. But the managerial consequences such as imposing sanctions on retailers, traders, and importers as well as launching campaigns to buy local products will direct peoples' willingness towards domestic products (ISAAC CHEAH, et al., 2016).

Kistruck et al. (2015) suppose that comparative advantage of intermediation is significant under three intertwining transaction conditions: customer heterogeneity, intermediation risk, company learning (KISTRUCK, et al., 2015). The research results of Topçu and Kaplan (2015) showed that consumers' ethnocentrism is negatively related to their willingness to buy foreign products and the judgment of domestic goods doesn't have a distinct and significant moderating effect in this regard (TOPÇU; KAPLAN, 2015).

The research of DaGuiso and Thio (2014) on the labels of food products states that five factors (low price, brand, advertising by word of mouth, consumer's perception and attitudes to product quality) affect the purchasing decision of 
consumers. The relationship between price and quality is also important (DAGUISO; THIO, 2014).

Ross (2006), believes that factors such as quality, design, features, variety, packaging etc. are more affecting factors in the production and sales and gaining competitive advantage (ROSS, 2006). Jackson (2005) believes that understanding the consumer behavior is a prerequisite to understanding how to stimulate or encourage consumer behavior (JACKSON, 2005).

Balabanis et al. (2001), in a research showed that more consumption nationalism is related to preferring domestic goods (BALABANIS, et al., 2001). Moon (2001), Watson and Wright (2000) state that if there is no suitable domestic products, the nationalist consumers will prefer products that are culturally and politically similar to their country or to the country which they export ratherthan other countries, and have more favorable opinions (MOON, 2001; WATSON; WRIGHT, 2000).

Similarly, according to the explanation and background of the subject, this article has dealt with identifying and prioritizing the factors affecting the customers' willingness to purchase domestic goods than the foreign ones in Iran Transfo Corporation in 2016. Because its products are as good as the foreign goods in terms of quality, and more affordable in terms of cost and price.

However, many customers still prefer imported goods from Italy, Russia and Poland, which reflects a weakness in the marketing, which requires support for the domestic goods from the government leading to economic growth and production. Preference for domestic products will be achieved once the domestic companies compete with foreign products through enhancing the product quality, and thinking to the international arena, as the saying goes "the greatest defense is to attack."

This is possible when factors affecting customers' willingness to buy domestic and foreign goods are identified and deficiencies and weaknesses are removed, so that besides satisfying and attracting domestic customers, they compete in the global market as well. Competition in the global market and more productions leads to increased prosperity of domestic industries among both domestic and international buyers, and all these factors require more labor in the production, sales and so on. 
INDEPENDENT JOURNAL OF MANAGEMENT \& PRODUCTION (IJM\&P)

http://www.ijmp.jor.br

v. 8, n. 3, July - September 2017

ISSN: 2236-269X

DOI: $10.14807 /$ ijmp.v8i3.622

\section{RESEARCH PURPOSES}

\section{1. main Purposes}

Identifying and prioritizing the reasons for customers' willingness to buy domestic or foreign goods.

\subsection{Secondary objectives}

a) Identifying and prioritizing the performance of domestic and foreign manufacturers according to the demands of customers.

b) Customers' assessment of the features of domestic goods compared to that of foreign goods.

c) Identification of customer satisfaction with the marketing methods of domestic goods compared to foreign goods.

d) Identification of competitive factors, such as the similarity of competitors and the competitive position with respect to organizational and environmental factors.

\section{THE THEORETICAL FRAMEWORK OF RESEARCH}

Internationalizing planning and business implementation, today has had a very pervasive effect on business. Market space has become an international competitive environment for all goods that affects business decisions in every corner of the world (DARLING; TAYLOR, 1996).

Due to this increase in competition, organizations have begun to present different strategic programs (WHITE; GRIFFITH, 1997) and according to the competition theories, creating sustainable competitive advantage is one of the primary objectives of companies and especially marketing strategies. When the company expands its activities in international markets, the first question that arises is whether the company can continue its existing marketing strategies to create sustainable competitive advantage.

Research on the benefits and costs of marketing strategy standardization has moved in three different directions. One stream argues in favor of standardization approach, the second stream supports adaptation, and the third and newer stream 
INDEPENDENT JOURNAL OF MANAGEMENT \& PRODUCTION (IJM\&P)

http://www.ijmp.jor.br

v. 8, n. 3, July - September 2017

ISSN: 2236-269X

DOI: 10.14807/ijmp.v8i3.622

supports creating a conditional framework that offers a degree of standardization (VISWANATHAN; DICKSON, 2007).

Standardization approach is using the same marketing methods in all countries, regardless of cultural differences. In contrast, the adaptation approach emphasized the adaptation of marketing methods tailored to local conditions in each country (KANSO; KITCHEN, 2004).

Debates on the standardization against adaptation date back to 1960s. Advocators of standardization approach refer to savings resulted from mass production, research, development and marketing as a result of convergence in consumer tastes and globalization of competition (BALABANIS, et al., 2001).

Experts and advocates argue that customers vary from one country to another. Advertising and other forms of promotion shall be dealt with tailored to the cultural needs of the country. Therefore, executives in different countries may face with unique obstacles such as potential differences in culture, tastes, media infrastructure, economic development and resentment or resistance towards attempts by companies to adjust their tastes and different cultures (KANSO; KITCHEN, 2004).

Green et al. (1975) found that customers with different methods look at the importance of various characteristics of the product in relation to their purchase behavior. Kanso in 1992 found that most companies conducted studies on this matter, have used adaptation approach and the standardization perspective is diminishing.

Altogether, he proposed that although the demands and needs of human beings are more or less the same, but the way by which these wishes and needs are met is not the same. [Ibid.204] Hence, international companies refine their goods and services to adapt to customer needs. By refining goods in accordance with needs of specific market, these companies are able to build strong customer relationships (WHITE; GRIFFITH, 1997).

Jane (1989), created a classification of four different factors that affect the standardization: factors of target market, market positioning factors, factors dependent on the nature of the goods, and organizational factors. 
INDEPENDENT JOURNAL OF MANAGEMENT \& PRODUCTION (IJM\&P)

http://www.ijmp.jor.br

v. 8, n. 3, July - September 2017

ISSN: 2236-269X

DOI: 10.14807/ijmp.v8i3.622

Colchalso noted that instead of thinking about absolute standardization, a global marketer should think about a degree of standardization and claimed that the desirable level of standardization will change from a product to another. He then showed that even if a product has all the globalization features, obviously it would not be able to use quite the same way for advertising in the worldwide.(Kanso \& Kitchen,2004)

The highest possible level of standardization is achieved when the homology of customers' response to the marketing mix and the similarity rate in economic freedom is high and competitive advantages are simply transferable. On the other hand, at the other end of the spectrum where the homology of customers' response to the marketing mix and the similarity rate in economic freedom is low and competitive advantages aren't simply transferable, standardization would be an irrational behavior in terms of competition (VISWANATHAN; DICKSON, 2007).

By accepting the conditional approaches of marketing approach standardization tailored to the requirements of each market, for success in business and competition managers should have a deep and identical understanding of the different attitudes and expectations of customers in the markets, in which they are competing (DARLING; TAYLOR, 1996).

The positive or negative assessment of the customer of foreign goods can definitely have a serious effect on different marketing decisions such as development of appropriate segmenting and positioning strategies and moderating marketing mix program in accordance with the customer's perceptions and modes of behavior in different countries (LEONIDOU; et al., 2007).

According to Fishbone in 1967, and Lancaster in 1966, customers always describe a product with a set of its features (MATSATSINIS, et al., 2007). Customers not only buy a product, but also a complete package of values under the title of market proposal. This proposal contains a series of elements such goods, goods services, transaction, brand, packaging, price, credit terms, price discounts, promotions and marketing, personal sales, the availability of store or business, inventory list, transportations and so on. Today, mixing and coordinating these different elements as a proper and integrated collection is raised as the primary 
INDEPENDENT JOURNAL OF MANAGEMENT \& PRODUCTION (IJM\&P)

http://www.ijmp.jor.br

v. 8, n. 3, July - September 2017

ISSN: 2236-269X

DOI: 10.14807/ijmp.v8i3.622

challenge for Chief Marketing Officers to develop a successful competitive position (DARLING; TAYLOR, 1996).

All research has shown that customer orientation towards goods and marketing methods related to it is very important in the market. Customer orientations towards various commodities that are available from different countries can be an important factor in determining the success of a company's marketing strategy.

The key points that creating distinction in advantages is derived only from goods and marketing methods that are significant to customers and the goal is to understand the stimuli of customer satisfaction and loyalty related to his willingness to consume and purchase specific foreign goods (WOOD, et al., 1999).

\section{CONCEPTUAL MODEL OF THE RESEARCH}

In this study, using a self-made questionnaire we examine the product features (reliability, market-product fit, product function), marketing method (reputation and validation, relative value, communication methods) and purchase preferences are measured and evaluated by different tests on the production of Iran Transfo Corporation, which leads to the presentation of an objective method to develop strategies and understand the stimuli that have greater effect on customer purchase preferences.

According to research from the theoretical model of Fishbone (1967) and Lancaster (1966). Thus, according to the variables the conceptual model of the research is as follows:

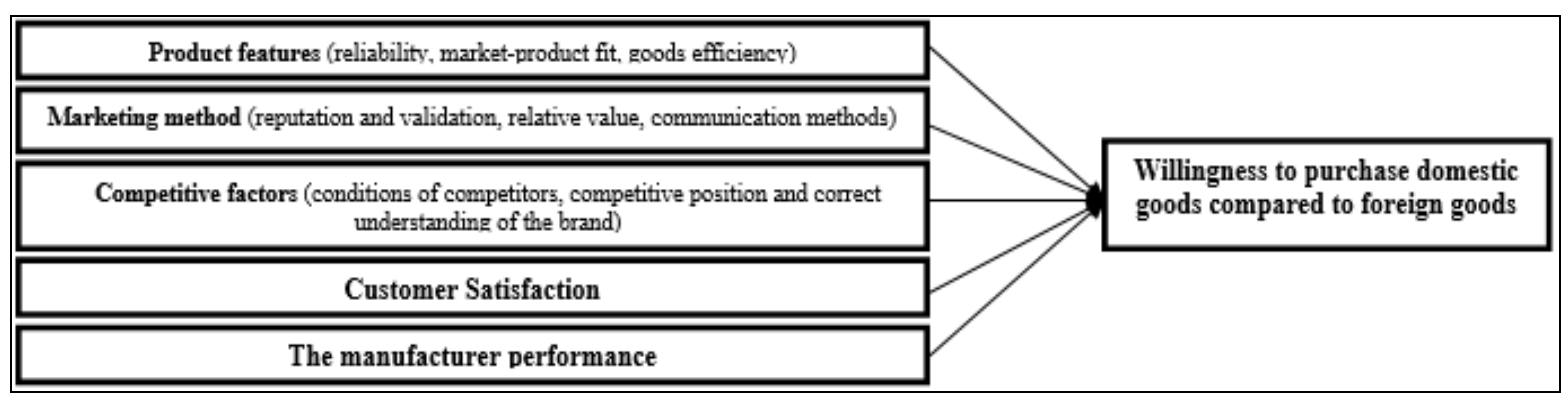

Figure1: conceptual model of the research -Factors affecting customers 'willingness to buy domestic products compared to the foreign ones

\section{METHODS}

It's a survey research (descriptive-correlation) carried out with two methods, namely, library and field method and distributing questionnaires among 200 domestic 
INDEPENDENT JOURNAL OF MANAGEMENT \& PRODUCTION (IJM\&P)

http://www.ijmp.jor.br

v. 8, n. 3, July - September 2017

ISSN: 2236-269X

DOI: $10.14807 /$ ijmp.v8i3.622

and foreign consumers of Iran Transfo Corporation and domestic companies consuming similar foreign products. The sample was selected randomly from among all presenters (customers) and sending electronic questionnaires.

\section{QUESTIONNAIRE OF FACTORS AFFECTING THE WILLINGNESS OF CUSTOMERS TO PURCHASE GOODS}

This self-made questionnaire includes questions such as (product features, workmanship, quality, reliability, competitiveness, advances of technology, product diversity, physical specifications, marketing methods, availability, after sale services, price, etc.) that can be tested using the Likert scale. Reliability of data using Cronbach's alpha also shows that items have an acceptable correlation (Table 1).

Table1: Cronbach's alpha test on the variable

\begin{tabular}{|l|c|c|}
\hline Variable & $\begin{array}{c}\text { Number of } \\
\text { items }\end{array}$ & $\begin{array}{c}\text { Cronbach's alpha } \\
\text { coefficient }\end{array}$ \\
\hline Reliability & 5 & 0.77 \\
\hline Market Fit & 5 & 0.89 \\
\hline Product function & 4 & 0.92 \\
\hline Marketing methods & 11 & 0.85 \\
\hline purchase preferences & 6 & 0.88 \\
\hline
\end{tabular}

\section{DATA ANALYSIS}

This study is applied in terms of purpose, and descriptive correlation in terms of data collection. The relationship between variables is analyzed in terms of purpose, using the SPSS software in two parts: descriptive and inferential statistics. Finally, based on the data collected, factors affecting customers' selection were used. In order to determine the final model and the correlation between independent and dependent variables multiple regression method was used (Inter) and prioritized.

\section{RESULTS}

\subsection{Descriptive statistics}

Demographic characteristics indicate that the $87.5 \%$ of respondents are male, and (55\%) are over 35 years and $42.5 \%$ between 25 - 34 years old. Given that the majority are employees of large companies of power distribution. As it was expected $100 \%$ of them have a university degree (71\% BA degree, $17.5 \% \mathrm{MA}$ degree, $6.5 \%$ Ph.D., 4.5\%Associate degree) and only $0.5 \%$ (1 person) of respondents had diploma and lower. (Table2). 
INDEPENDENT JOURNAL OF MANAGEMENT \& PRODUCTION (IJM\&P)

http://www.ijmp.jor.br

v. 8, n. 3, July - September 2017

ISSN: 2236-269X

DOI: 10.14807/ijmp.v8i3.622

Table 2: Demographic variables

\begin{tabular}{|c|c|c|c|}
\hline Variable & & & Percent \\
\hline \multirow{2}{*}{ Sex } & male & 175 & 87.5 \\
\cline { 2 - 4 } & Female & 25 & 12.3 \\
\hline \multirow{3}{*}{ Age } & $18-24$ & 5 & 2.5 \\
\cline { 2 - 4 } & $25-34$ & 85 & 42.5 \\
\cline { 2 - 4 } & 35 and above & 110 & 55 \\
\hline \multirow{4}{*}{ education } & Diploma or lower & 1 & 0.5 \\
\cline { 2 - 4 } & Associate & 9 & 4.5 \\
\cline { 2 - 4 } & Bachelors & 142 & 71 \\
\cline { 2 - 4 } & Masters & 35 & 17.5 \\
\cline { 2 - 4 } & Ph.D. & 13 & 6.5 \\
\hline
\end{tabular}

Product features and marketing methods: the majority of respondents agreed (55.9 \%) or strongly agreed (40.9\%) that Iranian goods have reliability, and in terms of market fit, only $9.5 \%$ believed that products didn't fit with the market, and $35.5 \%$ agreed, $25.5 \%$ strongly agreed that Iranian goods have a proper function. The majority of respondents (36.8\% agree, 31.3\% strongly agree) believed that the Iranian goods have a relative reputation and validity and $20.3 \%$ had no idea, $11 \%$ disagreed and $0.5 \%$ strongly disagreed. The respondents also (46.5\% agree and $18.5 \%$ strongly agree) stated that the Iranian goods have relative value and more than half of respondents (34.5 percent agree, 18.6\% strongly agree) stated that Iranian goods have an appropriate communication. Finally, most of respondents (56.5\% strongly agree, $31.2 \%$ agree) had a preference to purchase Iranian goods than other goods. (Table 3 )

Table 3. Components of the independent and the dependent variables

\begin{tabular}{|c|c|c|c|c|c|c|c|c|c|c|c|c|c|c|}
\hline \multirow[t]{2}{*}{ Component } & \multicolumn{2}{|c|}{ Reliability } & \multicolumn{2}{|c|}{ Market Fit } & \multicolumn{2}{|c|}{$\begin{array}{l}\text { Product } \\
\text { function }\end{array}$} & \multicolumn{2}{|c|}{$\begin{array}{c}\text { Relative } \\
\text { reputation and } \\
\text { validity }\end{array}$} & \multicolumn{2}{|c|}{ Relative Value } & \multicolumn{2}{|c|}{$\begin{array}{c}\begin{array}{c}\text { Modes of } \\
\text { communication }\end{array} \\
\end{array}$} & \multicolumn{2}{|c|}{$\begin{array}{c}\text { Purchase } \\
\text { preferences } \\
\text { (the dependent } \\
\text { variable) }\end{array}$} \\
\hline & Freq. & $\%$ & Freq. & $\%$ & Freq. & $\%$ & Freq. & $\%$ & Freq. & $\%$ & Freq. & $\%$ & Freq. & $\%$ \\
\hline $\begin{array}{l}\text { Strongly } \\
\text { disagree }\end{array}$ & 0 & 0 & 0 & 0 & 1 & 0.5 & 1 & 0.5 & 7 & 3.5 & 25 & 12 & 7 & 3.5 \\
\hline disagree & 0 & 0 & 19 & 9.5 & 38 & 19 & 20 & 11 & 6 & 3 & 15 & 7.7 & 0 & 0 \\
\hline No idea & 6 & 3.2 & 56 & 28 & 39 & 19.5 & 37 & 20.3 & 57 & 28.5 & 51 & 26.3 & 17 & 8.5 \\
\hline agree & 102 & 55.9 & 59 & 29.5 & 71 & 35.9 & 67 & 36.8 & 93 & 46.5 & 67 & 34.5 & 62 & 31.2 \\
\hline $\begin{array}{l}\text { strongly } \\
\text { agree }\end{array}$ & 76 & 40.9 & 66 & 33 & 51 & 25.9 & 57 & 31.3 & 37 & 18.5 & 36 & 18.6 & 113 & 56.8 \\
\hline Missing & 14 & - & - & - & - & - & 18 & - & - & - & 6 & - & 1 & \\
\hline Total & 200 & 100 & 200 & 100 & & & & & & & & & & \\
\hline
\end{tabular}


INDEPENDENT JOURNAL OF MANAGEMENT \& PRODUCTION (IJM\&P)

http://www.ijmp.jor.br

v. 8, n. 3, July - September 2017

ISSN: 2236-269X

DOI: $10.14807 /$ ijmp.v8i3.622

\subsection{Inferential Statistics}

The following tables represent the results of the t test, mean and standard deviation of variables towards purchasing goods from Iran Transfo Corporation and similar companies.

Table 4: T-test table of the two independent variables affecting the purchase preferences of domestic and foreign goods

\begin{tabular}{|c|c|c|}
\hline Components & T Value & The significance level (sig) \\
\hline $\begin{array}{c}\text { Willingness to } \\
\text { purchase }\end{array}$ & 4.61 & 0.000 \\
\hline Product features & 0.51 & 0.611 \\
\hline Marketing method & 2.18 & 0.032 \\
\hline $\begin{array}{c}\text { Performance of } \\
\text { manufacturers }\end{array}$ & 1.43 & 0.153 \\
\hline Customer Satisfaction & 5.81 & 0.000 \\
\hline
\end{tabular}

Table 5: The mean and standard deviation of purchasing foreign goods

\begin{tabular}{|c|c|c|c|c|c|}
\hline \multirow{11}{*}{ 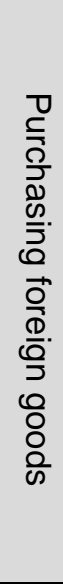 } & Component & & Number & Mean & $\begin{array}{l}\text { Standard } \\
\text { deviation }\end{array}$ \\
\hline & \multirow{2}{*}{$\begin{array}{l}\text { Willingness to } \\
\text { purchase }\end{array}$} & No & 73 & 26.75 & 2.79 \\
\hline & & Yes & 53 & 23.49 & 4.56 \\
\hline & \multirow{2}{*}{$\begin{array}{l}\text { Product } \\
\text { features }\end{array}$} & No & 73 & 52.71 & 11.22 \\
\hline & & Yes & 53 & 51.75 & 9.12 \\
\hline & \multirow{2}{*}{$\begin{array}{l}\text { Marketing } \\
\text { method }\end{array}$} & No & 73 & 40.50 & 9.29 \\
\hline & & Yes & 53 & 36.56 & 10.51 \\
\hline & \multirow{2}{*}{\begin{tabular}{|c|} 
Performance \\
of \\
manufacturers
\end{tabular}} & No & 73 & 93.21 & 18.68 \\
\hline & & Yes & 53 & 88. 32 & 19.18 \\
\hline & \multirow{2}{*}{$\begin{array}{l}\text { Customer } \\
\text { Satisfaction }\end{array}$} & No & 73 & 8.78 & 1.26 \\
\hline & & Yes & 53 & 7.37 & 1.38 \\
\hline
\end{tabular}

Now, for better evaluation, the results of the hypotheses in the research are presented as follows:

- Hypothesis 1: There is a significant difference between customers' willingness to purchase domestic goods and foreign goods. According to the $\mathrm{t}$-test and mean tables, $\mathrm{t}=4$.61shows a significance level and the hypothesizes confirmed because sig is less than 0.05 . Therefore, there's a difference between people who purchase domestic and foreign goods.

- Hypothesis 2: There is a significant difference between the customers' evaluation of the domestic and foreign product features. $\mathrm{T}=0.51$ and the significance level equals 0.611 which shows that the $t$ 
obtained is insignificant at this level, because sig is more than 0.05and the hypothesis is rejected.

- Hypothesis 3: There is a significant difference between the customers' evaluation of the marketing methods of domestic and foreign products. $T=2.18$ and the significance level equals 0.032 , which shows that the $t$ obtained is significant at this level, because sig is less than 0.05 and the hypothesis is confirmed. Mean table also shows the significance, meaning that there's a significant relationship between the customers' evaluation of the marketing methods of domestic and foreign products.

- Hypothesis 4: There is a significant difference between the manufacturers' performance of domestic and foreign products according to customers' demands. $\quad T=1.43$ and the significance level equals 0.153 which shows that the tobtained is insignificant at this level, because sig is more than 0.05 and the hypothesis is rejected.

- Hypothesis 5: There is a significant difference between customer satisfaction and willingness to purchase domestic and foreign goods. Results suggest that $T=5.81$ and the significance level equals 0.000 , which shows that the tobtained is significant at this level, and the hypothesis is confirmed. Mean table also shows the significance, therefore there's a significant relationship between customer satisfaction and willingness to purchase domestic and foreign goods.

\subsection{Multiple Regressions:}

Simultaneous multiple regression method was used to determine the final model and the correlation between independent and dependent variables (Inter), and the interpretation of the tables are shown below:

Table 6: The final model of correlation between independent and dependent variables

\begin{tabular}{|c|c|c|c|c|c|}
\hline Model & $\mathrm{R}$ & $\begin{array}{c}\text { The coefficient } \\
\text { of } \\
\text { determination }\end{array}$ & $\begin{array}{c}\text { Standardized coefficient of } \\
\text { determination }\end{array}$ & $\mathrm{F}$ & $\begin{array}{c}\text { The significance level } \\
\text { (sig) }\end{array}$ \\
\hline 1 & 0.680 & 0.463 & 0.429 & 13.535 & 0.000 \\
\hline
\end{tabular}


As seen, $\mathrm{R}$ equals to 0.68 , which represents a fairly good correlation between the variables. Also based on the adjusted coefficient of determination, it can be said that 0.42percent of changes in willingness to purchase foreign and domestic goods are explained by 7 variables. $F$ value is significant an error-level smaller than 0.05 and it can be concluded that the regression model of the research which is composed of 7 independent variables is a moderate model and the set of independent variables can explain $46 \%$ of the variance of the willingness to purchase Iranian and foreign goods. Table 7: The set of standard and non-standard coefficients for independent and dependent variables

\begin{tabular}{|c|c|c|c|c|c|}
\hline & $\begin{array}{c}\text { Non standardized } \\
\text { coefficients }\end{array}$ & $\begin{array}{c}\text { Standardized } \\
\text { coefficients }\end{array}$ & $\mathrm{T}$ & \multirow{2}{*}{$\begin{array}{c}\text { The significance } \\
\text { level (sig) }\end{array}$} & \\
\cline { 1 - 3 } & $\mathrm{B}$ & standard error & Beta & & \\
\hline (Constant) & 0.939 & 0.538 & & 3.601 & 0.000 \\
\hline Reliability & 0.079 & 0.020 & 0.364 & 3.934 & 0.000 \\
\hline Market Fitn & -0.104 & 0.020 & - & -5.230 & 0.000 \\
\hline $\begin{array}{c}\text { The function of the } \\
\text { product }\end{array}$ & 0.052 & 0.027 & 0.416 & 1.906 & 0.059 \\
\hline $\begin{array}{c}\text { The relative } \\
\text { reputation }\end{array}$ & -0.080 & 0.015 & - & -5.502 & 0.000 \\
\hline $\begin{array}{c}\text { The relative value } \\
\text { communications }\end{array}$ & -0.066 & 0.027 & - & -2.423 & 0.017 \\
\hline $\begin{array}{c}\text { Purchase } \\
\text { preferences }\end{array}$ & 0.039 & 0.018 & 0.347 & 2.117 & 0.037 \\
\hline
\end{tabular}

The table above shows the effect of independent variables on the dependent variable using the coefficients $B$. And the beta coefficient which is the standardized regression coefficient of each independent variable on the dependent variable, meaning that it specifies the relative share of each independent variable in the model. These factors suggest that the effect of 7 variables of reliability, market fit, product performance, marketing methods that includes (relative reputation, the relative value, and communication), and the purchase preferences are significant at the error level less than 0.05 .

Regarding the role of each share, and the role of each affecting dimensions in the model, the beta and its rate should be considered. According to the Table (24-4) and regression method in the entry of variables to the final model, it can be said that among the variables studied, the first variable that shows maximum affectivity has 
INDEPENDENT JOURNAL OF MANAGEMENT \& PRODUCTION (IJM\&P)

http://www.ijmp.jor.br

V. 8, n. 3, July - September 2017

ISSN: 2236-269X

DOI: 10.14807/ijmp.v8i3.622

market fit. In fact, it can be said that for each unit change in the standard deviation in the market fit, it affects the purchase of domestic goods.

The second affecting variable is the relative reputation and validity, and it can be said that for each one unit change in the standard deviation in relative reputation and validity of the product, it affects the purchase of domestic products by 0.44 . The third affecting variable is product function, and it can be said that for each unit change in the standard deviation in product function, it affects the purchase of domestic products by 0.41 .

The next effective variable is reliability of the product and it can be said that for each unit change in the standard deviation in product reliability, it affects purchasing domestic products by 0.36 . The next affective variable is the mode of communication and it can be said that for each unit change in the standard deviation in the communication modes, it affects the purchase of domestic products by 0.34 . And finally it is the relative value of the product that for each unit change in the standard deviation in the relative value of the goods, it affects the purchase of domestic products by 0.26 .

\section{DISCUSSION AND CONCLUSION}

The international market research on consumers' attitudes to domestic and foreign products and how they make decisions for purchasing, expresses two views: First, the logical data processing model that says consumers evaluate and select their need in a rational process affected by the cognitive components. The second one is the emotional model of processing information representing consumer choice affected by emotional factors.

In choosing between domestic and foreign goods, cognitive factors may include quality, price, availability, after sale services and availability of spare parts for domestic products, which leads to willingness of domestic products. So far, most researchers consider nationalism as an important factor in purchase preferences and many factors derived from the competitive advantage are not mentioned.

\section{THE RESULTS OF THE RESEARCH SHOWED THAT}

According to above, this study aims to identify and rank the factors affecting the customers' willingness to purchase domestic goods rather than foreign goods in Iran-Transfo Corporation by distributing 200 questionnaires among 26 companies 
the majority of customers $87.5 \%$ were male respondents aged 25 - 35 years and older $(97.5 \%)$ with undergraduate education.

- There is a significant difference between customers' willingness to purchase domestic goods and foreign goods

- There is a significant difference between the customers' evaluation of the domestic and foreign product features.

- There is a significant difference between the customers' evaluation of the marketing methods of domestic and foreign products.

- There is a significant difference between the manufacturers' performance of domestic and foreign products according to customers' demands.

- There is a significant difference between customer satisfaction and willingness to purchase domestic and foreign goods.

After prioritizing the factors affecting the purchase of domestic products, the results of the study has stated that, firstly, the market fit variable shows maximum effect. The second effective variable is the relative reputation and validity of the goods.

The third effective variable is the product function and then the product reliability, methods of communication and finally the relative value of the goods to purchase the goods of Iran Transfo Corporation. As a result, this research is consistent with many domestic research, such as research done by Sadeghi, et al. (2013), Mahmoudi Meymand, et al. (2012), Heidarzadeh, et al. (2009), Haghighi and HosseinZadeh (2008) and foreign studies such as Isaac Cheah, et al. (2016), Geoffrey M. Kistruck et al. (2015), Cenap T Opcu, Kaplan (2015), Thio and Da Guiso (2014), Ross (2006), Jackson (2005).

\section{SUGGESTIONS}

The results showed that products in Iran Transfo Corporation have no significant difference foreign products in terms of product features and people prefer domestic products rather than the foreign ones, but the company sales don't indicate so. After reviewing the marketing factors (in particular reputation and validity), the results showed that the company lacks an appropriate marketing method, and the 
INDEPENDENT JOURNAL OF MANAGEMENT \& PRODUCTION (IJM\&P)

http://www.ijmp.jor.br

v. 8, n. 3, July - September 2017

ISSN: 2236-269X

DOI: 10.14807/ijmp.v8i3.622

majority people believe that the goods have a relative reputation and validity, which was a major factor in selling failure. Accordingly, it is suggested that:

a) The companies adopt new policies for marketing their products.

b) The companies send trained marketer to different provinces.

c) Different training courses should be held in the areas of product quality and features of the product for managers and heads of departments that use this product.

d) A representative or agency should be located in various provinces to sell the product, so that consumers are ensured more than ever.

Given that many foreign researchers believe that nationalism and nationalist consumer (nationalism) has an enormous effect on selling domestic goods. Therefore, it's required to investigate the nationalism factor on this product as well.

\section{REFERENCE}

BALABANIS, G.; DIAMANTOPOULOS, A.; MUELLER, R. D.; MELEWAR, T. C. (2001) The impact of nationalism, patriotism and internationalism on consumer ethnocentric tendencies. Journal of International Business Studies, v. 32, n. 1.

DARLING, J. R.; TAYLOR, R. E. (1996) Changing attitudes of consumers towards the products and associated marketing practices of selected European countries versus the USA, 1975-95, European Business Review, v. 96, n. 3, p. 13-22

ELECTRONIC JOURNAL BHKAM (2016). http://vista.ir/article/220617

GEOFFREY, M.; KISTRUCK, S. S.; MORRIS, J. W.; WEBB, C. E.; STEVENSD, S. (2015) The importance of client heterogeneity in predicting make-or-buy decisions. Journal of Operations Management, n. 33-34, p. 97-110.

HAGHIGHI, M.; HOSEINZADEH, M. (2008). Compare rates tend to use domestic goods in Tehran and other parts of the world and explore its implications for assessment and product preferences, journal Human Sciences Research Lecturer in Management, Iran, v. 13, n. 4.

HEYDARZADEH, K.; HASANI PARSA, E. (2013) Effect of hedonistic values on consumer purchasing behavior, Journal of Marketing Management, n. 17, Winter.

HEYDARZADEH, K.; MOLLAREZA NIAROJI, R. (2014) After purchasing behavior of consumers: satisfaction or dissatisfaction, Islamic Azad University of Qazvin.

HEYDARZADEH, K.; ZANDHESAMI, H.; HASANLO, M. M. (2010) Evaluation desire (preferences) customers purchase decision making process of foreign goods, Journal of Marketing Management, n. 7.

ISAAC, C. H.; IAN, P.; GARICK, K.; YUAN, H. (2016) Modeling effects of consumer animosity: Consumers' willingness to buy foreign and hybrid products, Journal of Retailing and Consumer Services, n. 30, p. 184-192. 
JACKSON, T. (2005) Motivating Sustainable Consumption. Centre for Environmental Strategy, University of Surrey.

KANSO, A.; KITCHEN, P. J. (2004) Marketing consumer services internationally, Marketing Intelligence \& Planning, v. 22, n. 2, p. 201-215.

KNIGH, G. A. (1999) Consumer preferences for foreign and domestic products. Journal of Consumer Marketing, v. 16, n. 2, p.151-162.

LEONIDOU, L. C.; PALIHAWADANA, D.; TALIAS, M. A. (2007) British consumers'evaluations of US versus Chinese goods, European Journal of Marketing, v. 41, n. 7/8, p. 786-820

MAHMOODI MEYMAND, M.; VAZIRZANJANI, H. R.; KHALILI YADEGARI, M. (2013) Dimensions of personality test, the Myers-Briggs (MBTI) and the desire to buy customers, Journal of Marketing Research, n. 7, p. 165-151.

MATSATSINIS, N. F.; GRIGOROUDIS, E.; SAMARAS A. P. (2007) Comparing distributors' judgments to buyers' preferences, International Journal of Retail \& Distribution Management, v. 35, n. 5, p. 342-362.

MOON, B. J.; JAIN, S. C. (2001) Consumer processing of international advertising: the roles of country of origin and consumer ethnocentrism, Journal of International Consumer Marketing, v. 14, p. 89.

ROSS, S. D.; JAMES, J. D.; VARGAS, P. (2006), Development of the scale to measure Team brand Associations in professional sport, Journal of sport management, v. 20, n. 2.

SADEGHI, R.; KASHGAR, S.; GHASEMI, H.; KAREGAR, G. H. A. (2014) To determine the willingness of customers to buy foreign goods from the viewpoint of manufacturers, retailers and consumers, applied research in sport management, $v$. 2, n. 2 (6 row), fall, pp. 21-32.

THU, H. A.; NGUYEN, G.; AYDA, G. (2014) Factors that influence consumer purchasing decisions of Private Label Food Products A case study of ICA Basic. Dissertation.

TOPÇU, U. C.; KAPLAN, M. (2015) Willingness To buy foreign products in relation to ethnocentric tendencies and world minded attitudes of consumers, Procedia Social and Behavioral Sciences, n. 207, p. 157-164.

VISWANATHAN, N. K.; DICKSON, P. R. (2007) The fundamentals of standardizing global marketing strategy, International Marketing Review, v. 24, n. 1, p. 46-63.

WATSON J. J.; WRIGHT K. (2000) Consumer ethnocentrism and attitude toward domestic and foreign products. European Journal of Marketing, v. 34, n. 9/10.

WHITE, D. S.; GRIFFITH, D. A. (1997) Combining corporate and marketing strategy for global competitiveness, Marketing Intelligence \& Planning, n. 15/4, p. 173-178.

WOOD, V. R.; DARLING, J. R.; SIDERS, M. (1999) Consumer desire to buy and se products in international markets. International Marketing Review, v. 16, n. 3, p. 231-256. 